\title{
Glusoce-6-phosphate dehydrogenase- History and diagnosis
}

\section{Gautam K ${ }^{1}$}

${ }^{\prime}$ Department of Pathology, Samyak Diagnostic Pvt. Ltd, Lalitpur, Nepal

\section{Keywords: \\ G6PD; \\ Primaquine; \\ Neonatal Jaundice}

\begin{abstract}
Glucose-6-phosphate dehydrogenase deficiency is the most common enzymatic defect of red blood cells, which increases the vulnerability of erythrocytes to oxidative stress leading to hemolytic anemia. Since its identification more than 60 years ago, much has been done with respect to its clinical diagnosis, laboratory diagnosis and treatment. Association of G6PD is not just limited to anti malarial drugs, but a vast number of other diseases. In this article, we aimed to review the history of Glucose-6-phosphate dehydrogenase, the diagnostic methods available along with its association with other noncommunicable diseases.
\end{abstract}

\section{INTRODUCTION}

Glucose-6-phosphate dehydrogenase (G6PD) deficiency is the most common enzymatic defect of red cells. G6PD deficiency increases the vulnerability of erythrocytes to oxidative stress leading to hemolytic anemia. Sixty years ago 3 enzyme deficiencies that produce disease in humans had been identified, all in human erythrocytes. These enzymes were catalase, galactose-1-phosphate uridyltransferase, and glucose-6-phosphate dehydrogenase. ${ }^{1}$ Although the technology was not so advance at that time, a lot was accomplished regarding the diagnosis of G6PD

\section{Correspondence:}

Dr. Keyoor Gautam, MBBS, MD

Consultant Pathologist

Department of Pathology, Samyak Diagnostic Pvt. Ltd, Lalitpur, Nepal Email:drkeyoor@gmail.com deficiency, its genetic predisposition as well as the disease management. Globally, 400 million people are estimated to be affected with this enzymatic disorder of red blood cells (RBCs), most of which are seen in the tropical and subtropical zones of eastern hemisphere., ${ }^{2,3}$ Although a large number of individuals are affected with this enzyme deficiency, fortunately only few present with a clinically relevant symptom.

\section{History}

In the year 1926, Cordes reported the occurrence of acute hemolysis in individuals treated for malaria with 6-methoxy-8-aminoquinoline drugs, however the mechanism of hemolysis could not be understood for the next three decades. ${ }^{4}$ The discoveries that lead to the 
Table 1 : Classification of G6PD deficiencies following the WHO recommendations

\begin{tabular}{|c|c|c|c|c|c|}
\hline Class & $\begin{array}{l}\text { Residual enzymatic } \\
\text { activity }\end{array}$ & Protein location & Clinical symptoms & $\begin{array}{l}\text { Frequency and geo- } \\
\text { graphical distribution }\end{array}$ & Type of mutation \\
\hline $\mathbf{I}$ & $<1 \%$ or not detectable & $\begin{array}{l}\text { Dimer interface Struc- } \\
\text { tural NADP }\end{array}$ & $\begin{array}{l}\text { Chronic hemolytic ane- } \\
\text { mia }\end{array}$ & $\begin{array}{l}\text { Rare and without a pre- } \\
\text { cise geographical distri- } \\
\text { bution }\end{array}$ & $\begin{array}{l}\text { G6PD-Buenos } \\
\text { G6PD Durban }\end{array}$ \\
\hline II & $<10 \%$ & $\begin{array}{l}\text { Dimer interface NADP } \\
\text { binding site }\end{array}$ & $\begin{array}{l}\text { Acute hemolytic anemia } \\
\text { fava beans and drug de- } \\
\text { pendent }\end{array}$ & $\begin{array}{l}\text { Frequent and distributed } \\
\text { throughout the world }\end{array}$ & $\begin{array}{l}\text { G6PD-Mediterranean } \\
\text { G6PD-Cassano G6PD- } \\
\text { Santamaria }\end{array}$ \\
\hline III & $10-60 \%$ & $\begin{array}{l}\text { Scattered throughout the } \\
\text { whole enzyme }\end{array}$ & $\begin{array}{l}\text { Occasionally acute he- } \\
\text { molytic anemia }\end{array}$ & $\begin{array}{l}\text { Very frequent in malaria } \\
\text { areas }\end{array}$ & $\begin{array}{l}\text { G6PD-A- G6PD-Seattle } \\
\text { G6PD-Canton G6PD- } \\
\text { Rignano }\end{array}$ \\
\hline IV & $60-90 \%$ normal activity & Neutral protein site & Asymptomatic & Undefined frequency & $\begin{array}{l}\text { G6PD-Mont a lbano } \\
\text { G6PD-Orissa }\end{array}$ \\
\hline $\mathbf{V}$ & $>110 \%$ increased activity & $\begin{array}{l}\text { Neutral protein site or } \\
\text { promoter mutations }\end{array}$ & Asymptomatic & Undefined frequency & Not reported \\
\hline
\end{tabular}

recognition of G6PD deficiency were the result of several convergent events. The biochemical pathways through which red cells metabolize sugar were established., ${ }^{5,6}$ The tools available then seem incredibly primitive today, but by 1950 , virtually every step in red cell glycolysis was established. Secondly, the development of isotopic methods permitting the accurate estimation of red blood cell survival was essential. It was the ${ }^{51} \mathrm{Cr}$ method of labeling erythrocytes, first devised by Sterling and Gray to measure the red cell mass and subsequently adapted for measuring the cell survival, that set the stage for the studies that had to be performed. ${ }^{7}$ Finally the circumstances surrounding World War II and the Korean War had created the necessity for the development of new, synthetic antimalarial drugs. The funding required to carry out the studies materialized from the United States Army. Volunteers serving sentences in the Illinois State Penitentiary at Joilet were selected for conducting the clinical investigation on understanding why 8 -amino quinoline antimalarials caused hemolysis. ${ }^{6}$ When normal volunteers were given $30 \mathrm{mg}$ of primaquine daily, some developed acute hemolytic anemia; most did not. Did those who developed hemolytic anemia metabolized this 6-methozy-8-amino quinoline anitmalarial drug differently, or did their red ells differ in some manner? Development of ${ }^{51} \mathrm{Cr}$ technique made it possible to answer this question. When ${ }^{51} \mathrm{Cr}$ labeled cells form a primaquine-sensitive subject were transfused into a nonsensitive subject, primaquine administration resulted in rapid destruction of the labeled erythrocytes. But when ${ }^{51} \mathrm{Cr}$ labeled cells from a non sensitive subject were transfused into a primaquine sensitive subject, they survived normally even when the host's red cells were being rapidly destroyed. These studies established clearly that sensitivity to the hemolytic effect of primaquine was due to an intrinsic defect of the erythrocyte. ${ }^{6}$

There were few morphological changes in the red cells of subjects undergoing primaquine-induced hemolysis, but Heinz bodies could be detected in the circulation before the onset of hemolysis. Heinz bodies can be induced in vitro by compounds such as phenylhydrazine or acetyl phenlyhydrazine, and we were able to show that the pattern of in vitro Heinze body formation was quite different in sensitive and nonsensitive subjects. ${ }^{8}$ This made it possible, for the first time, to detect primaquine sensitivity in vitro. The fact that iodoacetate and arsenite caused normal cells to behave like primaquine sensitive cells focused attention on the sulfhydryl groups of the erythrocyte. The amount of glutathione in the cells was diminished, and the ability of erythrocytes to maintain glutathione levels in the face of oxidative stress was abnormal. ${ }^{9}$ Latter on Carson undertook a study of the reduction of glutathione by hemolysates. When it was found that hemolysates from primaquine sensitive men could not utilize glucose-6-phosphate to reduce glutathione, the more expensive NADPH was added as the hydrogen donor. This substrate could reduce glutathione in hemolysates from primaquine sensitive men, making it apparent that the primary defect was in the glucose-G-phosphate utilizing enzyme, G6PD. ${ }^{10}$

\section{Genetics and Classification}

G6PD enzyme is encoded by a human X-linked gene (Xq2.8) consisting of 13 exons and 12 introns, spanning nearly 20 $\mathrm{kb}$ in total; the first exon is noncoding, while the remaining 12 range from 120 to $235 \mathrm{bp}$. It has over 400 allelic variants know. These variants have been biochemically characterized based on: (a) the different residual enzyme activities, (b) electrophoretic mobility patterns, and (c) physiochemical or kinetic properties. ${ }^{11}$ G6PD variants are grouped into five classes based on WHO guidelines (Table 1).

\section{Pathophysiology}

Red cells are vulnerable to injury by oxidants. Abnormalities in the hexose monophosphate shunt or glutathione metabolism resulting from deficient or impaired enzyme function reduce the ability of red cells to protect themselves against oxidative injuries, leading to hemolytic disease. As noted in Figure 1, G6PD reduces NADP to NADPH while oxidizing glucose-6-phosphate. NADPH then provides reducing equivalents needed for conversion of oxidized glutathione to reduced glutathione, which protects against 


\begin{tabular}{l} 
Table 2: Drugs and chemicals to be avoided by persons \\
with G6PD deficiency \\
\hline Acetanilide \\
\hline Diaminodiphenyl sulfone \\
\hline Furazolidone (Furoxone) \\
\hline Glibenclamide \\
\hline Henna (Lawsone) \\
\hline Isobutyl nitrate \\
\hline Methylene blue \\
\hline Naphthalene \\
\hline Niridazole (Ambilhar) \\
\hline Nitrofurantoin \\
\hline Phenazopyridine \\
\hline Phenylhydrazine \\
\hline Primaquine \\
\hline Sulfacetamide \\
Sulfanilamide \\
\hline Sulfapyridine \\
Thiazolesulfone \\
Trinitrotoluene \\
\hline Urate oxidase \\
\hline
\end{tabular}

oxidant injury by catalyzing the breakdown of compounds such as $\mathrm{H} 2 \mathrm{O} 2$. In simpler terms, the disposal of $\mathrm{H} 2 \mathrm{O} 2$, a potential oxidant, is dependent on the adequacy of reduced glutathione (GSH), which is generated by the action of NADPH. The synthesis of NADPH is dependent on the activity of G6PD. ${ }^{11}$

\section{Clinical spectrum of G6PD deficiency}

The clinical spectrum of G6PD deficiency has been identified in a vast number of conditions. Clinical manifestations depend on the degree of the enzyme deficiency, which in turn is determined by the characteristics of the G6PD variant. Majority of individuals are asymptomatic and do not have hemolysis in the steady state. They have neither anemia, evidence of increased red blood cell destruction, nor an alteration in blood morphology, although a modest shortening of RBC survival can be demonstrated by isotopic techniques. However, episodes of acute hemolysis with hemolytic anemia may be triggered by medications, certain foods, and acute illnesses, especially infection. ${ }^{12}$

\section{Drug induced hemolysis}

The hemolytic effect of primaquine in G6PD deficient individuals were already established. But later on it was realized that the spectrum of drugs that caused hemolysis was much more than that had been anticipated. Transfusing labeled red cells from a few primaquine sensitive donors into a larger number of nonsensitive recipients and then challenging the sensitive cells with a variety of drugs made it possible to quantitate the extend to which each drug produced hemolysis. ${ }^{6,13,14}$ Table 2 lists drugs that have been shown to be capable of producing clinically significant hemolytic anemia in doses that are normally used. Table 3 indicates qhich drugs can be given safely to most patients with G6PD deficiency. ${ }^{15,16}$

\section{Foods inciting hemolysis}

Certain foods can induce hemolysis in a G6PD deficient individual. Intravascular hemolysis induced by ingestion of fava beans, known to as favism, is a well know cause and is seen predominantly in young males age 1 to 5 years. Symptoms include headache, back pain, chills, fever within 24 hours of ingestion, followed by hemoglobinuria and jaundice. An important thing to be noted is that all patient with favism are G6PD deficient, but many G6PD deficient individuals can eat fava beans with impunity. Thus, the deficiency is a necessary but not sufficient cause of hemolysis. It has been suggested that the glycosides divicine and isouramil are the components of the bean responsible for a hemolysis, but there is no rigorous proof that this is the case, and the additional factor that makes a minority of G6PD deficient individuals develop hemolysis when they ingest the bean is still unknown, although it is probably inherited.

\section{Infection}

Infection is the most common cause of acute hemolysis in G6PD-deficeinet persons, although the exact mechanism by which this occurs is unknow. Leukocytes may release oxidants during phagocytosis that cause oxidative stress to the erythrocytes; however, this explanation alone would not account for the variety of infections associated with hemolysis in G6PD deficient persons. The most common infections agents causing hemolysis include Salmonella, Escherichia coli, beta-hemolytic streptococci, rickettsial infections, viral hepatitis, and influenza A. ${ }^{17}$

\section{Neonatal Jaundice}

Anemia and jaundice are often first noted in neonates with severe G6PD deficiency. The principle cause of neonatal icterus in G6PD deficient infants is the inability of the liver to adequately conjugate bilirubin. This problem is compounded when the infant also inherits the UDP glucuronosyl transferase promoter polymorphism that is associated with Gilbert disease. As noted, hyperbilirubinemia is likely secondary to impairment of bilirubin conjugation and clearance by the liver leading to indirect hyperbilirubinemia. G6PD deficiency can lead to an increased risk and earlier onset of hyperbilirubinemia, which may require phototherapy or exchange transfusion. In certain populations, hyperbilirubinemia secondary to G6PD deficiency results in an increased rate of kernicterus and death, whereas in other populations this has not been observed. This may reflect genetic mutations specific to different ethnic groups. 


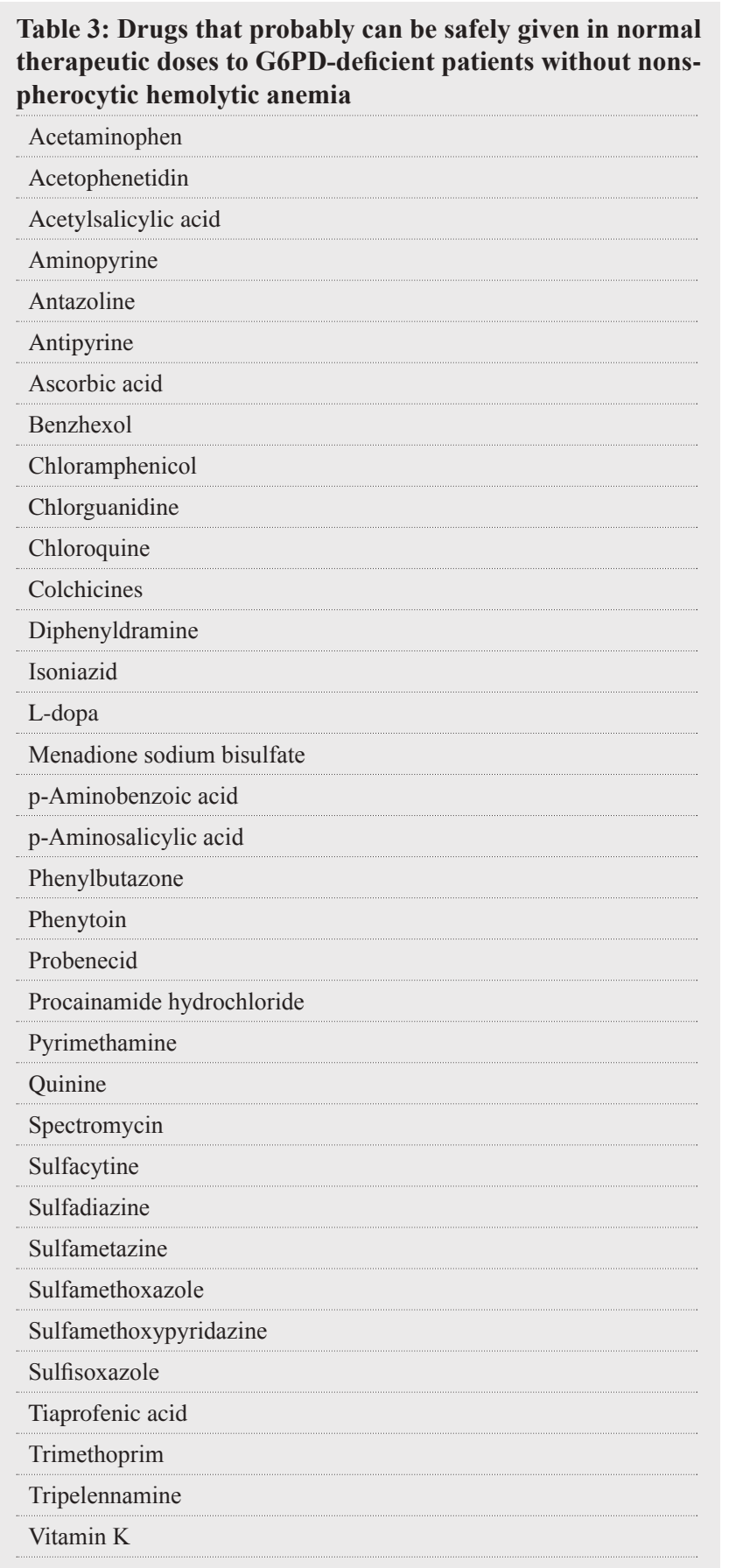

\section{Congenital nonspherocytic hemolytic anemia and chronic hemolysis}

Chronic hemolysis is not characteristic of most individuals with G6PD deficiency, but those with severe deficiency can have chronic hemolysis with or without chronic anemia. Variants that produce chronic hemolytic anemia are referred to as class I variants. These individuals have such severe G6PD deficiency that they may have hemolysis even in the absence of oxidant injury from medications or illnesses. ${ }^{18,19}$

These individuals may also be referred to as having congenital nonspherocytic hemolytic anemia. The term nonspherocytic is somewhat of a misnomer, since these individuals may have spherocytes on the pheripheral blood smear. However, this term is useful in distinguishing individuals with G6PD deficiency, in whom spherocytes are relatively infrequent at baseline, from those with hereditary spherocytosis, in whom spherocytes are abundant. The severity of hemolysis varies, causing mild hemolysis to transfusion dependent anemia. Exposure to oxidative stress can cause acute hemoysis in these persons. ${ }^{20}$

\section{Cardiovascular disease}

The clinical effects of G6PD deficiency on the heart remains largely unexplored despite it being the most common known enzyme deficiency in the world. Although studies suggest that G6PD deficiency may decrease superoxide production in failing myocardium and that G6PD deficiency may decrease the risk of developing coronary heart disease, recent studies in mice indicate increased oxidative stress in G6PD deficient failing myocardium and that G6PD deficiency adversely affects the development of heart failure.

The effects of G6PD deficiency on the development and progression of heart failure in human patients could be explored by screening hypertensive patients for G6PD deficiency and then following these patients over an extended period to see whether g6PD deficiency affects the development of heart failure in these patients. Another study could examine G6PD deficient patients who have already developed heart failure to determine whether G6PD deficiency positively or negatively affects prognosis. Thus

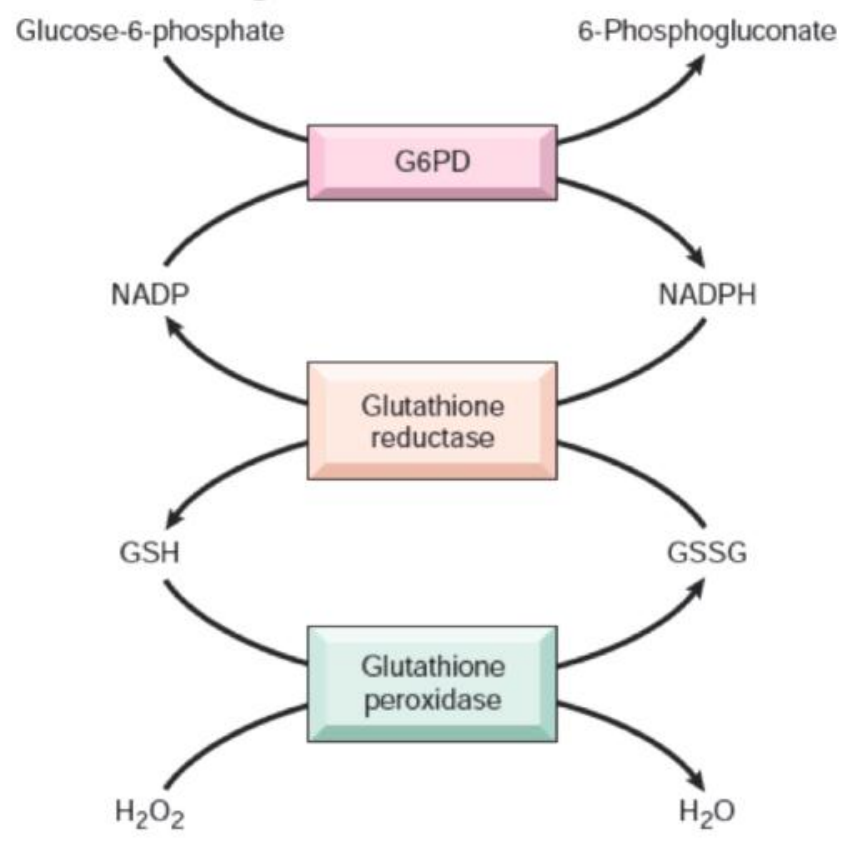

Figure 1: : Role of glucose-6-phosphate dehydrogenase in defense against oxidant injury. 
the development of heart failure should be examined in G6PD deficient patients. Overall, G6PD deficiency may decrease the rate of cardiovascular disease development among humans through its effect on atherogenesis. ${ }^{21}$

Meloni has concluded that subjects with G6PD deficient phenotype are less prone to coronary heart disease (CHD). They suggest that such a protective effect may be ascribable to a reduced 3-hydroxy-3-methylglutaryl-coenzyme A reductase (HMG-CoA R) activity, a statin-like effect, as well as to a downregulation in NADPH oxidase activity with a consequent reduction in oxygen free radical production. ${ }^{22}$

\section{G6PD activity in Diabetic patients}

Diabetes mellitus is a common and complicated disease. Activities of enzyme G6PD is important in preventing its complications. Unsuitable control of blood glucose decreases G6PD activity and increases diabetes mellitus complications. This issue itself aggravates diabetic injury due to inappropriate antioxidation process. Simultaneous dyslipidemia and obesity may intensity the effect of hyperglycemia and oxidative stress. G6PD activity level can reflect the gylcemic control, and even predict subsequent complications while they are not present Literature has shown that G6PD mean activity in diabetics is significantly lower than non diabetics. Various studies have concluded that reduced activity of G6PD is a risk factor for DM. Since diabetic patients simultaneously suffer from other endocrine problems like dyslipidemia, it is worthy to evaluate the impact of such associated abnormalities on G6PD activity. Comparing G6PD activity between dyslipidemic and non dyslipidemic patients within diabetics and comparing G6PD activity between non diabetic and dyslipidemic diabetic patients, the researchers showed that its activity was significantly lower in dyslipidemic patients. ${ }^{23}$

On the other hand studies have also concluded that G6PD deficiency showed a trend for protection against diabetes with proliferative diabetic retinopathy. Further experimental and clinical studies are necessary for a better understanding of the mechanism by which G6PD deficiency may affect diabetes and its retinal vascular complications. ${ }^{24}$

\section{Laboratory Tests}

Enzymatic evaluation: The WHO recommends the diagnosis of G6PD deficiency utilizing universal tests, mainly based on the generation of NADPH from NADP.

Semiquantitative assays are as follows: (i) fluorescent spot test, which is rapid, simple, sensitive and inexpensive. This test method is used in countries where G6PD deficiency is both frequent and malaria endemic, before starting treatment with antimalarial drugs, such as primaquine. A variant of the spot test, not requiring the sue of an ultraviolet lamp but a naked eye evaluation, allows the larger population screening in the tropical areas. (ii) other screening tests available which determine the NADPH concentration indirectly, by measuring the reduced methemoglobin levels produced after NADPH oxidation. (iii) Finally, the Heinz body examination and GSH stability test may be employed to distinguish G6PD deficient from normal individuals.

For a biochemical definitive diagnosis, a quantitative analysis is mandatory done by spectrophootometry. Diagnostic issues can arise when G6PD activity is measured after or during an episode of acute hemolysis, or in the presence of high blood reticulocyte count, being the reticulocytes activity about five times higher than that of old RBCs, resulting in a false negative result. Because protein synthesis is absent in RBCs, the activity of G6PD, and of other enzymes gradually decreases during RBCs aging, which will be selectively destroyed. If any acute intravascular hemolytic G6PD dependent anemia is suspected, any potentially dangerous drugs must be discontinued and the test should be rerun 10-15 days after, or later, if the patient has been transfused. In these cases, genetic analysis or family study, when available, can improve the diagnostic tool. For a complete diagnostic assessment of the G6PD deficiency rate, the following laboratory parameters are also important: RBCs and reticulocyte counts, total and indirect plasma bilirubin, plasma iron and lactate dehydrogenase levels, serum haptoglobin and urine hemoglobin concentration. ${ }^{11}$

\section{Molecular diagnosis}

Molecular analysis may be useful for population screening, family studies, or parental diagnosis, although this approach is not used routinely. For a correct laboratory practice, the molecular diagnosis of G6PD deficiency should employ two analytical steps: 1) a first screening level, to research the most frequent mutations belonging to a specific geographical area. In this case, a PCR coupled to RFLP represents a rapid valid, and reliable molecular screening approach; 2) a second level, based on the whole gene sequencing, finalized to the identification of the less frequent, or novel, mutation. 25

DNA based test for the screening of the most frequent mutations in a specific geographical area can be used as an alternative tool to the biochemical assay. The costs for chemicals dedicated to molecular test are comparable to those used for the enzyme assay. In the future, more advance systems should be utilized to improve the efficiency of the molecular assay. ${ }^{11}$

\section{CONCLUSION}

G6PD deficiency is one of the most common enzyme defect of red cells which has been studied for more than 50 years since its identification. Point of care testing has helped in screening individuals prior to administration of malarial drugs. Molecular testing has been important in identifying the different variants which have clinical significance. 


\section{REFERENCES}

1. Takahara S, Miyamoto H. Three cases of progressive oral gangrene due to lack of catalase in the blood. Nippon Jibinkoka Gakkai Kaiho 1948;51:163.

2. Mason PJ, Bautista JM, Gilsanz F. G6PD deficiency: the genotypephenotype association. Blood Rev 2007;21:267. Crossref

3. Cappellini MD, Fiorelli G. Glucose-6-phosphate dehydrogenase deficiency. Lancet 2008;317;64. Crossref

4. Cordes W. Experiences with plasmochin in malaria. In: anonymous. 15th Annual report. Boston, MA: United Fruit Co;1926:66-71.

5. Beutler E. The red cell: a tiny dynamo. In: Wintrobe MM, Ed. Blood Pure and Eloquent. New York, NY: McGraw-Hill, Inc;1980.p141-68.

6. Beutler E. Glucose-6-phosphate dehydrogenase deficiency: a historical perspective.Blood 2008;111:16-24. Crossref

7. Sterling K, Gray SJ. Determination of the circulating red cell volume in man by radioactive chromium. J Clin Invest. 1950;29:1614-9. Crossref

8. Beutler E, Dern RJ, Alving AS. The hemolytic effect of primaquine, VI: an in vitro test for sensitivity of erythrocytes to primaquine. J Lab Clin Med. 1955;45:40-50. Crossref

9. Beutler E, Dern RJ, Flanagan CL, Alving AS. The hemolytic effect of primaquine, VII: biochemical studies of drug sensitive erythrocytes. J Lab Clin Med. 1955;45:286-95. Crossref

10. Carson PE, Flangan CL, Ickes CE, Alving AS. Enzymatic deficiency in primaquine sensitive erythrocytes. Science. 1956;124:484-5. Crossref

11. Aster JC. Red blood cell and Bleeding disorders, In: Kumar V, Abbas A, Fausto N, (eds). Pathologic Basis of Disease. 7th edn. Saunders: Philadelphia; 2007. pp 627-8.

12. World health Organization Working Group. (1989) Glucose6-phosphate dehydrogenase deficiency. Bull. World Health Organ.67,601-11.

13. Brewer GJ, T AR, Kellermeyer RW. The hemolytic effect of primaquine. Shortened erythrocyte life span in primaquine sensitive male negroes in the absence of drug administration. J Lab Clin Med $1961 ; 58: 217-24$
14. Dern RJ, Beutler E, Alving AS. The hemolytic effect of primaquine, $\mathrm{V}$ : primaquine sensitivity as a manifestation of a multiple drug sensitivity. J Lab Clin Med 1955;45:30-9. Crossref

15. Beutler E. Disorders of red cells resulting from enzyme abnormalities. In: Lichtman MA, Beutler E, Kipps TJ, Seligsohn U, Kaushansky K, Prachal J, eds. Williams Hematology. New York, NY: MaGrawHill;2006.p603-31.

16. Beutler E. Hemolytic Anemia in Disorders of Red Cell Metabolism. New York. NY: Plenum Press, Inc; 1978. Crossref

17. Beutler E. G6PD deficiency. Blood 1994;84:3613-36. Crossref

18. Beutler E, Mathai CK, Smith JE. Biochemical variants of glucose6-phosphate dehydrogenase giving rise to congenital nonspherocytic hemolytic disease. Blood 1968;31:131. Crossref

19. Grossman A, Ramanathan K, Justice P. Congenital nonspherocytic hemolytic anemia associated with erythrocyte glucose-6-phosphate dehydrogenase deficiency in a Negro family. Pediatrics 1966;37:624. Crossref

20. Mason PJ. New insights into G6PD deficiency. Br J Haematol 1996;94:585-91. Crossref

21. Hecker PA, Leopold JA, Gupte SA, Recchia FA, Stanley WC. Impact of glucose-6-phosphate dehydrogenase deficiency on the pathophysiology of cardiovascular disease. Am J Physiol Heart Circ Physiol. 2013;304: H491-500. Crossref

22. Meloni L, Manca MR, Loddo I, Muntoni Sa. Glucose-6-phosphate dehydrogenase deficiency protects against coronary heart disease. Journal of Inherited Metabolic Disease 2008;31:412-7. Crossref

23. Rashidi H, Shafiei M, Hamidian R. Erythrocytic glucose-6phosphate dehydrogenase activity in diabetic patients. Pak J Med Sci 2009;25:665-8.

24. Pinna A, Contini EL, Carru C, Solinas G. Glucose-6-phosphate dehydrogenase deficiency and diabetes mellitus with severe retinal complications in a Sardinian Population, Italy. Int J Med Sci 2013;10:1907-13. Crossref

25. Minucci A, Giardina B, Zuppi C, Capoluongo E. Glucose-6phosphate dehydrogenase laboratory assay: How, When, and Why? Life 2009;61:27-34. Crossref 